\title{
Black root rot caused by Rosellinia pepo, a new disease of the clove tree in Brazil
}

\author{
Marival L. Oliveira ${ }^{1}$, Gustavo L. Melo², Ana Rosa R. Niella ${ }^{1}$ \& Valdívia R. Silva ${ }^{1}$ \\ ${ }^{1}$ Comissão Executiva do Plano da Lavoura Cacaueira - CEPLAC, Seção de Fitopatologia, Cx. Postal 07, 4560-970, Ilhéus, \\ BA, Brazil; ${ }^{2}$ Departamento de Agronomia, Universidade Estadual de Santa Cruz, 45660-000, Ilhéus, BA, Brazil
}

Corresponding author: Marival L. Oliveira, e-mail: marival@cepec.gov.br

\begin{abstract}
The clove tree is an evergreen plant of the family Myrtaceae that reaches more than 12 meters in height. It originates from the Moluccas, Indonesia, and was introduced in Brazil by the Portuguese. The plant is cultivated mainly in the Lower South region of the state of Bahia, which is also where cacao is grown in Brazil. Cloves are mainly used for culinary purposes, both whole and in ground forms. During disease surveys in the municipality of Ituberá, Bahia, in 2006, clove trees were observed showing symptoms of wilting, chlorosis and death, with the dry leaves remaining attached to the branches for some time. Occasionally, especially on older plants, only part of the tree exhibited such symptoms, with leaves falling and leaving the plant defoliated. Up to the collar level, diagnostic disease symptoms and signs of the pathogen were observed on the root system. Beneath the bark, white mycelial fans, star-like, typical of the fungus Rosellinia pepo, were observed on the wood. The anamorph, Dematophora sp., was isolated in PDA and inoculated on four-month-old clove plants, after being cultivated for twenty days in a medium prepared with maize flour and pieces of dry cacao leaves $(1: 1 \mathrm{w} / \mathrm{w})$. The first disease symptoms and the signs of the pathogen were observed 32 days after inoculations, with the fungus being re-isolated from all the inoculated plants. This is the first report of R. pepo on the clove tree.
\end{abstract}

Keywords: Syzygium aromaticum, Dematophora sp., eugenol, root rot disease.

\section{RESUMO}

Podridão-negra causada por Rosellinia pepo, uma nova doença do craveiro-da-índia no Brasil

O craveiro-da-índia, planta da família Myrtaceae, que atinge normalmente mais de 12 metros de altura, é originária das Ilhas Molucas, Indonésia, e foi introduzida no Brasil pelos portugueses. A planta é cultivada, principalmente, na região conhecida como Baixo Sul, local onde também se cultiva cacaueiro no sul da Bahia. Seu principal uso é na culinária, tanto na forma in natura quanto industrializada. Durante levantamentos realizados no município de Ituberá, em 2006, foram observados craveiros apresentando sintomas de murcha, amarelecimento e seca das folhas as quais permaneciam aderidas às plantas por algum tempo. Dependendo da idade, apenas uma parte da planta exibia tais sintomas, ocorrendo progressivamente sua desfolha e morte. Ao se inspecionar o sistema radicular, até ao nível do coleto, observavase os sintomas diagnósticos da doença e os sinais típicos do patógeno. Após a remoção da casca, notava-se sobre o lenho, a presença de rizomorfas esbranquiçadas, em forma de leque ou estrela, típicas do fungo Rosellinia pepo. Dematophora sp., seu anamorfo, foi isolado em BDA e inoculado em mudas de cravo com quatro meses de idade, após ser cultivado por 20 dias em um meio preparado com fubá-de-milho e secções de folhas secas de cacaueiro $(1: 1 \mathrm{p} / \mathrm{p})$. Os primeiros sintomas da doença e os sinais típicos do patógeno foram observados 32 dias após as inoculações, sendo o fungo re-isolado de todas as plantas inoculadas. Este é o primeiro relato do fungo $R$. pepo causando podridão de raiz em craveiro-da-índia.

Palavras-chave: Syzygium aromaticum, Dematophora sp., eugenol, podridão de raízes.

\section{INTRODUCTION}

The clove tree [Syzygium aromaticum (L.) Merr. \& L.M. Perry] is an evergreen plant of the family Myrtaceae that reaches between 12 and 15 meters in height. The tree can live for 100 years and there are some individual records of plants reaching 150 years old (Pursglove et al., 1981). The main use of cloves is for culinary purposes, due to their aroma and outstanding flavor conferred by eugenol, a phenolic volatile compound. Clove is also used by the pharmaceutical industry for medicine production, perfumery and dentistry, mostly in antiseptic and analgesic products for mouth hygiene, as well as for production of other phenolic compounds, such as vanillin (Pursglove et al., 1981; Mazzafera, 2003). In leaves, eugenol represents around $95 \%$ of the extracted oil, and in the dried spice, it constitutes the main component of the oil, varying from 70 to $85 \%$ (Brown \& Morra, 1995). Its commercial production is based, mainly, on the spice. Some works have shown that the plant extracts can present, as well as eugenol, nematicide (Tsao \& Yu, 2000), insecticide (El-Hag et al., 1999), antiviral (Yukawa et al. 1996), bactericide (Dorman \& Deans, 2000) 
and fungicide activities (Delespaul et al., 2000).

The clove tree originated from the Moluccas, Indonesia. Initially it was spread to the other islands of the archipelago and, later on, to other countries by the colonizers (Pursglove et al., 1981; Mendes Ferrão, 1993). The world's largest producers of cloves are Indonesia, Tanzania (Zanzibar and Pemba) and Madagascar. It is also important in Malaysia, Sri Lanka and Haiti (Mendes Ferrão, 1993; Mazzafera, 2003).

The clove tree probably was introduced in Brazil during the Portuguese colonization (Mendes Ferrão, 1993). In southern Bahia, the main clove-growing region of Brazil, it is not possible to precisely define when the plant was first cultivated; however, most of the clove-growing areas of the state were planted in 1968, although very old clove plantations can be easily found in the municipalities of Ituberá and Nilo Peçanha. The plant has adapted very well to the region, making the state of Bahia the largest producer of the spice in Brazil. As a consequence of excellent soil and climate conditions, the crop is commercially exploited, mainly in the Lower South and in the municipality of Una, also located in the southern part of the state.

Sudden-death disease, the most important phytopathological threat to the clove industry in Bahia, had no defined etiology for years, until the fungus Ganoderma philippii (Bres. \& Henn. ex Sacc.) Bres. was proven to be its causal agent (Oliveira, 1992b). Another fungus, Valsa eugeniae Nutman \& F.M. Roberts, which is the causal agent of sudden-death disease of clove in Zanzibar and Malaysia (Nutman \& Roberts 1971), had been also isolated from roots of clove (Bezerra, 1993), but was not the main threat in Brazil.

There are also other clove diseases, including die-back and canker caused by Cryphonectria cubensis Bruner \& Hodges (syn. Endothia eugeniae (Nutman \& Robert) J. Reid \& C. Booth) (Nutman \& Robert, 1971), and some others of minor importance, such as leaf spots caused by Cylindrocladium quinqueseptatum Boedjin \& Reitsma, Colletotrichum coccodes (Wallr.) S. Hughes (syn. Gloeosporium piperatum Ellis \& Everh.), Colletotrichum capsici (Syd.) E.J. Butler \& Bisby, Phyllostictina sp., Pycnothyrium sp., tread blight caused by Corticium sp., and a slow decline induced by Phytophthora cinnamomi Rands (Waller \& Sitepu, 1975; Pursglove et al., 1981). A new species of Ceratocystis, C. polychrome, associated with $S$. aromaticum was reported from Sulawesi (van Wyk et al., 2004). Despite the existence of these many clove diseases in other countries, G. philippii and V. eugeniae are still the only fungi to have been isolated from the crop in Brazil.

During disease surveys conducted in Ituberá to investigate the causes of the high clove tree mortality, some plants exhibiting different symptoms from those reported for the disease now known as red root rot, caused by the fungus G. philippii, were observed. The symptoms and signs of the pathogen were, however, quite similar to those induced by the fungus Rosellinia pepo Pat. in a series of plants already reported as hosts in Bahia, such as cacao (Theobroma cacao) and immortelle (Erythrina spp.) (Oliveira, 1992a), or nutmeg (Myristica fragans) (Oliveira et al., 2007b), rubber tree (Hevea brasiliensis), cupuassu (Theobroma grandiflorum), and mangosteen (Garcinia mangostan) (M.L. Oliveira, data not published).

Therefore, the aim of these studies was to investigate, under field, laboratory and greenhouse conditions, the possible causes for the high mortality of clove trees observed in southern Bahia. Part of this research has been reported previously (Oliveira et al., 2007a).

\section{MATERIAL AND METHODS}

Disease surveys were conducted on some farms in the municipality of Ituberá, in southern Bahia, in 2006, to investigate the possible causes for high clove tree mortality. Observations on the disease symptoms were carried out not only in this crop, but also on rubber and cupuassu trees cultivated near cacao plantations, since all of them exhibited the same kind of symptoms and signs of the pathogen. Samples from infected plants were taken to the Plant Pathology Laboratory, at the Cacao Research Center (CEPEC), in Ilhéus, Bahia (BA), Brazil, for further analysis, isolations and identification of the pathogen. All the assays were conducted under field, greenhouse and laboratory conditions at CEPEC.

The isolations were carried out from infected roots after washed in running tap water, to remove soil and plant debris; and the root surface sterilized with $1 \%$ sodium hypochlorite. Tissue sections obtained with a sterilized pocket-knife from the transition zone between diseased and healthy tissues were once again surface sterilized with $1 \%$ sodium hypochlorite, washed in sterile distilled water, dried in filter paper, inserted in 9-cm Petri dishes containing PDA medium (potato, 200g; dextrose, 20g; agar, 15g; water, $1000 \mathrm{~mL}$ ) and incubated at $25^{\circ} \mathrm{C}$, in the dark. Fivemillimeter-diameter mycelial disks, taken with a sterilized cork borer from the advancing margins of 8 to 10-day-old colonies grown on PDA, were transferred to the center of Petri dishes containing the same medium. After being sealed with Parafilm ${ }^{\circledR}$ the agar plates were incubated at $25^{\circ} \mathrm{C}$, in the dark, until the fungi had completely developed.

After being identified under the optical microscope, using glass slide preparations, the most predominantly isolated fungus was grown on a medium prepared with maize flour and pieces of dry cacao leaves (MFCL) to be used in the pathogenicity tests (Figure 1A). The MFCL medium was prepared by mixing equal amounts of the ingredients $(1: 1 \mathrm{w} / \mathrm{w})$ after distilled water had been added and the medium submitted to a cooking period of 30 minutes. Fifteen-centimeter-diameter Petri dishes, containing the MFCL medium, were inoculated with 5-millimeter-diameter mycelial disks taken from the advancing margins of 8 to 10 day-old colonies growing on PDA and incubated at $25^{\circ} \mathrm{C}$, in the dark, for 20 days. Twenty grams of the inoculum 

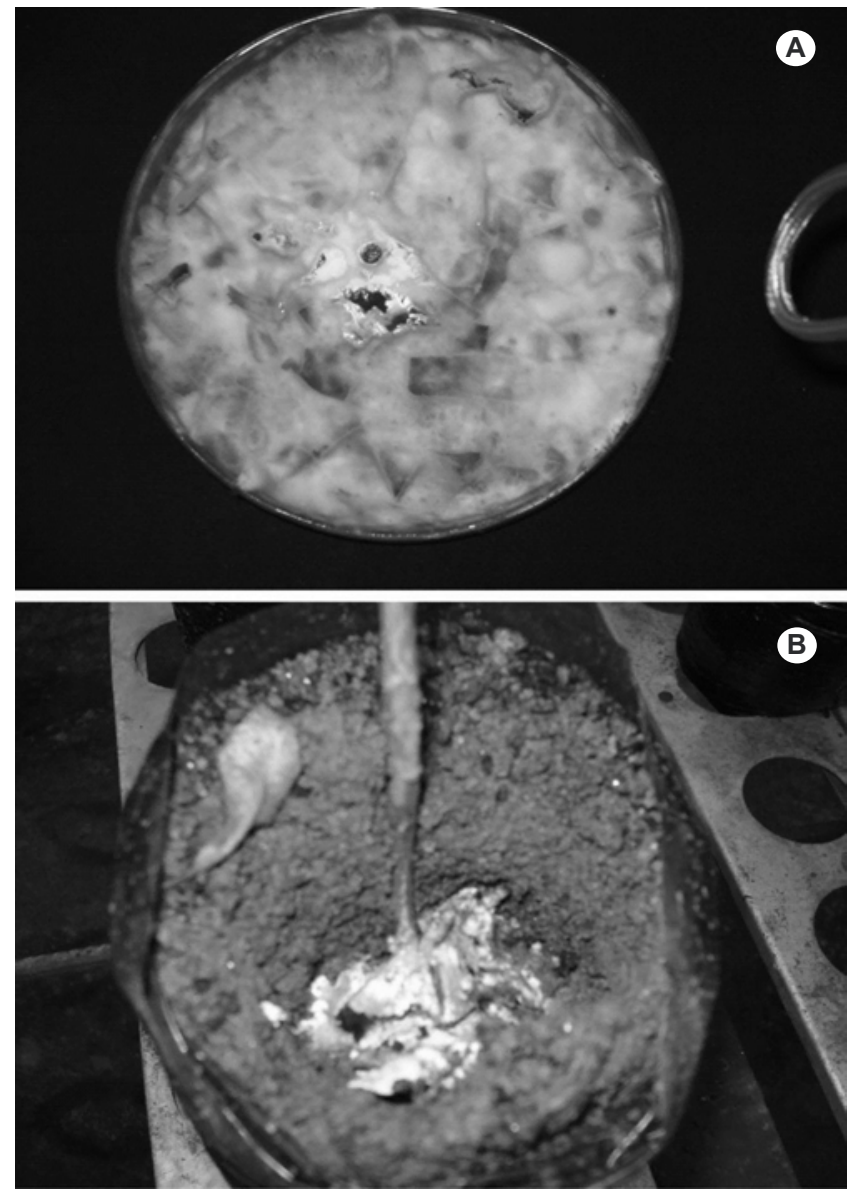

FIG. 1 - Method of inoculation. A. Conidial state of Rosellinia pepo (Dematophora sp.) grown on a medium prepared with maize flour and pieces of dry cacao leaves $(1: 1 \mathrm{w} / \mathrm{w})$; B. clove seedling inoculated with the fungus after removing the superficial layer of soil.

(mycelium plus medium) were used to inoculate each of 10 four-month-old clove seedlings, maintaining an equal number of plants, without inoculum, as controls. Plant inoculations were carried out after removing the superficial layer of soil to a depth of $7 \mathrm{~cm}$. The lateral and the taproot were exposed and slight wounds were made in the root system using a sterilized pocketknife. Twenty grams of inoculum were placed in contact with the roots, after which the removed soil was put back in the original location (Figure 1B). Inoculated seedlings were maintained under greenhouse conditions $\left(25^{\circ} \mathrm{C}\right.$, $90 \%$ humidity) and inspected, periodically, until the appearance of the symptoms and death of the plants. Dead seedlings were removed from the soil; the roots were washed in running tap water and examined for detection of rhizomorphs and other disease symptoms and signs of the fungus, and then re-isolation of the pathogen took place.

\section{RESULTS}

During the surveys conducted on Ituberá farms, clove trees were observed exhibiting symptoms of wilting, yellowing, leaf drying, root rot and death of plants, with the dry leaves remaining attached to the branches, for some time (Figure 2A). The disease now known as black root rot could occur on trees of all ages; however, in older plants it was observed that if the damage was more severe on one side of the root system, the aerial symptoms would also be more severe on that side of the tree. In these cases, the leaves were gradually shed before they became fully necrotic, leading to defoliation and, later on, to the plant's death.

Up to the collar level, characteristic symptoms of the disease and signs of the pathogen were observed on the root system, where the presence of rhizomorphs was usually associated with root rot (Figure 2B). Beneath the bark, white mycelial fans or star-like mycelia, typical of the fungus $R$. pepo, were observed on the wood surface (Figure 2C).

The conidial state of $R$. pepo, referred to in the literature as a Dematophora type, was predominantly isolated from the samples collected on infected plants exhibiting the same kind of symptoms as those observed on several other plants that had already been reported as hosts of $R$. pepo in southern Bahia. The pathogen was identified as Dematophora sp., which is also considered to be the anamorph of other Rosellinia species, such as R. bunodes (Berk \& Broome) Sacc. (Booth \& Holliday, 1972). The pathogen identification was based not only on the presence of typical signs of the fungus in the root system (Figure 2c), but also on its characteristic structures, the synnemata, developed on MFCL medium and examined under the optical microscope (Figure 2d).

Among the media used for the production of inoculum, MFCL was the best one. When 4-month-old clove seedlings were inoculated using this medium, there was a complete reproduction of the disease symptoms and signs of the pathogen, with the first dead plants appearing 32 days after the beginning of the assays. Although there was no uniformity in terms of appearance of the symptoms, since the plants did not die at the same time, the method of inoculation was efficient in the reproduction of all the disease symptoms and signs of the pathogen observed under field conditions (Figure 2e). The medium was also efficient for the production of the characteristic morphological structures of the anamorph, the synnemata.

\section{DISCUSSION}

Among the well-known root pathogens, in both temperate and tropical perennial plants, are Rosellinia necatrix Berl. ex. Prill. and R. desmazieri (Berk. \& Broome) Sacc., mostly from temperate zones, and $R$. bunodes, $R$. pepo and $R$. arcuata Petch, known only in the tropics. Rosellinia necatrix is the most common root pathogen and occurs in all five continents. Rosellinia pepo and $R$. bunodes 

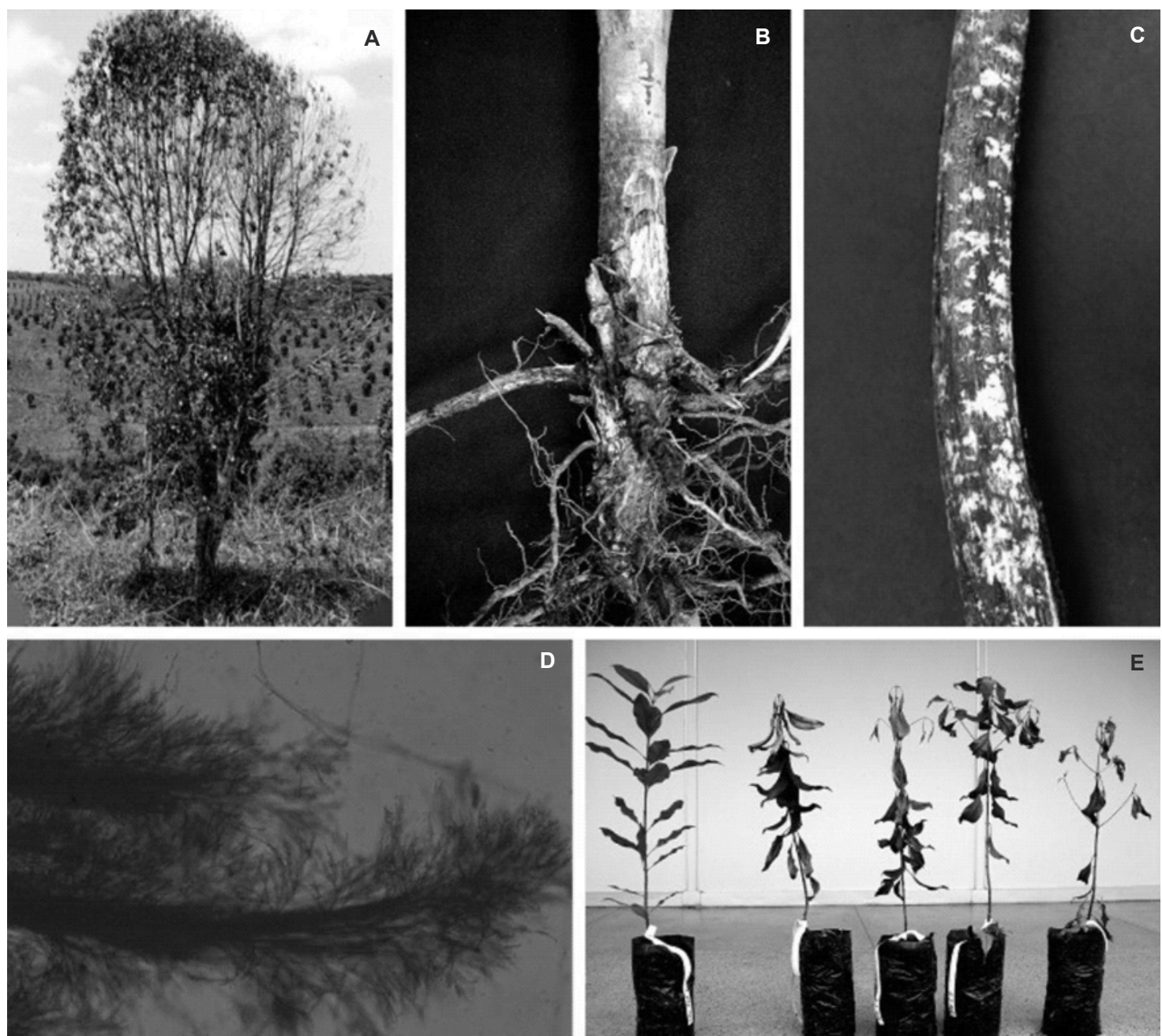

FIG. 2 - Symptoms and signs of black root rot disease on clove tree caused by Rosellinia pepo. A. dead plant showing dry leaves held to the tree; B. presence of rhizomorphs associated with root rot, up to the collar level; $\mathbf{C}$. white mycelial fans, star-like, typical of the infection of the fungus, beneath the bark; D. characteristic structures of the anamorphic phase of the fungus (synnemata); E. inoculated clove seedlings showing typical symptoms of the disease.

are more restricted, and $R$. pepo is supposed to be more so than $R$. bunodes, which is the most aggressive and prevalent species (Waterston, 1941; Booth \& Holliday, 1972; Hoppen \& Krauss, 2006). Both species occur in tropical areas in Central and South America, West Africa, The West Indies and Asia (Waterston, 1941; Hoppen \& Krauss, 2006).

At the worldwide level, there are only three species of Rosellinia causing root rot on cacao, a plant cultivated in southern Bahia, the same region where the clove tree is grown in Brazil: R. pepo, R. bunodes and R. paraguayensis Starbäck. So far, only the first two species have been reported in Bahia (Oliveira, 1992a).

The anamorph of $R$. pepo, Dematophora sp., was the main fungus isolated from all the samples collected in plants exhibiting symptoms of wilting, yellowing, leaf drying, root rot and plant death during the surveys directed to investigate the causes for the high clove tree mortality in southern Bahia, in 2006. Rosellinia pepo has also been the pathogen most often isolated from roots of other plants already reported as hosts of the fungus in Bahia, as mentioned before.

Although $R$. bunodes and $R$. pepo have a more restricted host range than some other species of the genus, they are, however, very important pathogens causing serious economical problems in numerous cash crops and tree species like coffee (Coffea spp.), rubber tree, lime (Citrus aurantifolia), avocado (Persea americana), pigeon pea (Cajanus cajan), camphor (Cinnamomum comphora), cassava (Manhiot esculenta), taro (Xanthosama sp.), black 
pepper (Piper nigrum), tea (Camellia sinensis), nutmeg, Inga spp., to name a few (Waterston, 1941; Hoopen \& Krauss, 2006). However, no references were found in the literature, at the worldwide level, referring to $R$. pepo as the causal agent of any disease on the clove tree.

Despite the fact that $R$. bunodes is considered the most aggressive and prevalent species on several hosts in other countries (Waterston, 1941; Gibson, 1978), the fungus was only reported on just two occasions in Bahia: on cacao (Oliveira, 1992a) and on coffee (M.L. Oliveira, data not published). It is possible to conclude that there is a clear prevalence of the species $R$. pepo on the plants already reported as hosts in southern Bahia.

When grown on MFCL medium, Dematophora sp. was able to produce the characteristic vegetative structure, the synnemata. Speciation in the genus Rosellinia is normally based on its teleomorphic structures; however, some problems may arise as it can be difficult to obtain the teleomorph (Hoopen \& Krauss, 2006). Thus, the identification of the pathogen during this work was based on the vegetative structures only, since the occurrence of peritecia under field conditions has not been observed so far.

All the 4-month-old clove seedlings inoculated with Dematophora sp., presented the same kind of symptoms observed under field conditions. The method of inoculation developed in this work, using the MFCL medium, was efficient for the complete reproduction of the disease symptoms and signs of the pathogen, with the first dead seedlings appearing 32 days after the beginning of the assays.

Black Root rot diseases induced by species of Rosellinia may cause serious economic threats to woody plants, especially on recently deforested lands, due to their spreading mechanism. Normally, their dissemination is based on the contact between infected and healthy roots or even on fungal growth on the organic matter in the soil. The survival of Rosellinia species also takes place in the soil organic matter, particularly on infected roots and other plant debris (Waterston, 1941; Oliveira, 1992a).

Generally, root diseases caused by species of Rosellinia occur in patches that show a circular pattern due to the way in which the pathogen infects neighboring plants, based normally on root-to-root contact. The amount and availability of organic matter on the soil surface could explain, in part, the higher relative importance of the disease in some places and hosts than in others. The fungus can disseminate itself through mycelial growth on the organic matter (Gibson, 1978; Oliveira, 1992a; Hoppen \& Krauss, 2006), and also be favored by rainwater carrying infected materials and plant debris throughout the soil surface. However, the role that ascospores and sclerotia play on the disease epidemiology is not so clear (Hoopen \& Krauss, 2006).

In cacao plantations, for example, the amount of organic matter on the soil surface is usually greater than in other crops. As mentioned previously, this fact could explain the apparently higher importance of the disease on cacao than on the clove tree (Oliveira, 1992a). In Bahia, in areas of low rainfall frequency, where little organic matter accumulation is normally observed, or in plantations under low shade and uneven relief, the disease incidence can be insignificant. Under such conditions, the disease spreads slowly, limiting itself to small foci, and taking place, predominantly, by contact between diseased and healthy roots. This is the first worldwide report of the fungus $R$. pepo as the causal agent of root rot on the clove tree.

\section{REFERENCES}

Bezerra JL (1993) Primeiro relato de Valsa eugeniae causando morte de craveiro-da-ínida na Bahia. Fitopatologia Brasileira 18:487.

Booth C, Holliday P (1972) Rosellinia pepo. CMI Descriptions of Pathogenic Fungi and Bacteria 351:1.

Brown PD, Morra MJ (1995) Glucosinolate-containing plant tissues as bioherbicides. Journal of Agricultural and Food Chemistry 43:3070-3074.

Delespaul Q, Billerbeck VG, Roques CG, Michel G, MarquierVinuales C, Bessiere JM (2000) The antifungal activity of essential oils as determined by different screening methods. Journal of Essential Oil Research 12:256-266.

Dorman HJD, Deans S (2000) Antimicrobial agents from plants: antibacterial activity of plant volatile oils. Journal of Applied Microbiology 88:308-316.

El-Hag EA, El-Nadi AH, Zaitoon AA (1999) Toxic and growth retarding effects of three plant extracts on Culex pipiens larvae (Diptera: Culicidae). Phytotherapy Research 13:388-392.

Gibson IAS (1978) Rosellinia bunodes (Berk. \& Br.) Sacc. In: Kranz, J, Schmutterer H, Koch W (Eds.) Diseases, pests and weeds in tropical crops. New York NY. John Wiley \& Sons. pp. 135-136.

Hoppen GM, Krauss U (2006) Biology and control of Rosellinia bunodes, Rosellinia necatrix and Rosellinia pepo: a review. Crop Protection 25:89-107.

Mazzafera P (2003) Efeito alelopático do extrato alcoólico do cravo-da-índia e eugenol. Revista Brasileira de Botânica 26:231238.

Mendes Ferrão JE (1993) Especiarias - cultura, tecnologia, comércio. Lisboa. Instituto de Investigação Científica Tropical.

Nutman FJ, Roberts FM (1971) The clove industry and the diseases of the clove tree. Pest Articles News Summaries 17:147-165.

Oliveira ML (1992a) Podridão negra da raiz do cacaueiro causada por Rosellinia spp., no Brasil. Agrotrópica 4:21-26.

Oliveira ML (1992b) Ganoderma philippii causando podridão vermelha na raiz do craveiro-da-índia. Agrotrópica 4:27-32.

Oliveira ML, Melo GL, Niella ARR, Silva VR (2007a) Black root rot of clove tree caused by Rosellinia pepo in southern Bahia. Fitopatologia Brasileira 32(Supl.):286. 
Oliveira ML, Sacramento CK, Bezerra JL, Cerqueira ARRN, Silva VR (2007b) Podridão-negra da raiz da noz-moscadeira causada por Rosellinia pepo. Agrotrópica 18:89-92.

Pursglove JW, Brown EG, Green CL, Robbins SRJ (1981) Spices. Vol. 1. London. Longman.

Tsao R, Yu Q (2000) Nematicidal activity of monoterpenoid compounds against economically important nematodes in agriculture. Journal of Essential Oil Research 12:350-354.

van Wyk M, Roux J, Barnes I, Wigfield BD, Liew ECY, Assa B, Summerell BA, Wingfield MJ (2004) Ceratocystis polychroma sp. nov., a new species from Syzygium aromaticum from Sulawesi. Studies in Mycology 50:273-282.

Waller JM, Sitepu D (1975) Sumatra disease of clove in Indonesia. Pest Articles News Summaries 21:141-147.

Waterston JM (1941) Observations on the parasitism of Rosellinia pepo Pat. Tropical Agriculture 18:174-184.

Yukawa TA, Kurokawa M, Sato H, Yoshida Y, Kageyama S, Hasegawa T, Namba T, Imakita M, Hozumi T, Shiraki K (1996) Prophylactic treatment of cytomegalovirus infection with traditional herbs. Antiviral Research 32:63-70. 